\title{
Pendampingan Pembuatan Logo Elvita Bakery and Cake
}

\author{
Fauziyah \\ Program Studi Manajemen, STIE Widya Gama Lumajang \\ zfauzya@gmail.com
}

\begin{abstract}
Abstrak
Logo merupakan identitas perusahaan, lembaga ataupun usaha yang dikelola oleh perseorangan yang menggambarkan citra dari si pemilik perusahaan tersebut. Kekuatan logo mampu menjadi pengingat yang sangat kuat di benak konsumen atau publik terhadap perusahaan atau lembaga tersebut. Dalam kegiatan Pengabdian kepada masyarakat ini, penulis menggunakan metode pendampingan secara intensif kepada pemilik usaha Elvita Bakery and Cake sebagai sasaran dalam kegiatan ini, untuk melakukan pembuatan logo. Selain itu penulis juga mengajak diskusi tentang bagaimana konsep logo yang akan dibuat. Hasil dari kegiatan ini adalah terselesaikannya logo Elvita Bakery and Cake. Harapannya dengan adanya logo ini mampu meningkatkan performa perusahaan Elvita Bakery and Cake.
\end{abstract}

\section{Kata Kunci : Pendampingan, Logo, Elvita Bakery and Cake}

\begin{abstract}
The logo is the identity of the company, institution or business managed by an individual that describes the image of the owner of the company. The power of the logo can be a very strong reminder in the minds of consumers or the public towards the company or institution. In this community service activity, the author used the method of intensive assistance to business owners Elvita Bakery and Cake as a target in this activity, to make logos. In addition, the author also invited a discussion about how the concept of the logo will be made. The result of this activity was the completion of the Elvita Bakery and Cake logo. The hope is that with this logo, it can improve the performance of the company Elvita Bakery and Cake.
\end{abstract}

Keywords: Assistance, Logo, Elvita Bakery and Cake.

\section{PENDAHULUAN}

Membuka usaha atau bisnis baru memang bukan perkara yang mudah tetapi bukan juga tergantung bakat. Banyak faktor yang memengaruhi seperti perubahan teknologi dan persaingan pasar yang kian ketat. Ketatnya persaingan ini semakin memaksa kita untuk melakukan inovasi dan kreatifitas dalam segala bidang dalam melancarkan strategi bisnis dan marketing yang handal untuk memenangkan pertempuran merebut pangsa pasar ataupun mempertahankan pangsa pasar yang sudah dengan susah payah dikuasai.

Mengamati pasar, mengenali kompetitor hingga menilai potensi pasar adalah hal wajib dan penting untuk dilakukan sebelum memilih strategi mana yang akan dipakai. Ada banyak cara dalam memilih dan menerapkan strategi yang dianggap terbaik. Strategi yang tersediapun sudah sangat banyak seperti blue ocean strategy, red ocean straegy, new waves 
marketing, gen-y marketing dan lain-lain. Dikarenakan masing-masing pakar marketing dan bisnis memiliki pandangan tersendiri.

Terdapat perbedaan yang sangat jelas antara Red Ocean Strategy (ROS) dan Blue Ocean Strategy (BOS). ROS mengharuskan adanya kompetisi dengan produk lain dalam satu arena market space yang sama. Sebuah brand harus mampu memukul brand lain yang lebih kuat melalui logika kompetisi. Risikonya adalah harus berjuang dengan sangat keras. Sementara BOS menawarkan sebuah logika yang sebaliknya. Ia mencoba untuk menciptakan market space yang berada di luar panggung kontestasi. Ia menciptakan dan menangkap permintaan baru (new demand) sehingga membuat kompetisi sudah tidak lagi relevan. (Suwatno, 2017 : 74).

Tetapi dari semua hal yang telah disebut diatas yang paling penting dan paling sering dilupakan banyak perusahaan adalah pentingnya logo pada kemasan produk dan tidak sedikit pula perusahaan yang tidak memiliki logo untuk produk mereka. Seberapa jitu dan hebatnya strategi bisnis dan marketing sebuah perusahaan apabila melupakan logo pada kemasan produk atau logo produk akan sangat sulit untuk berhasil karena logo merupakan pintu gerbang kedalam pikiran konsumen seperti yang telah ditulis oleh pakar marketing terkemuka Philips Kotler.

Logo seperti fungsinya yang telah kita bahas pada: Fungsi Logo Bagi Perusahaan, adalah sebagai simbol pengingat produk bagi konsumen. Jadi penggunaan sebuah logo pada produk atau kemasan produk akan membantu konsumen mengingat produk kita lebih mudah. Pada dunia otomotif atau elektronik misalnya konsumen akan kesulitan membedakan sebuah mobil yang satu dengan yang lain apabila pada produk tersebut tidak diberikan logo sebagai pembeda. Sebuah telepon genggam Blackberry akan sangat sulit dibedakan dengan Samsung Galaxy apabila tidak diberikan logo Blackberry yang terkenal itu. Bahkan pada bidang industri sparepart, Honda selalu mencantumkan logonya secara besar dengan menggunakan hologram pada kemasan produk sebagai tanda keaslian dan jaminan kualitas produk tersebut.

Pemakaian logo pada produk atau kemasan produk dapat meningkatkan gengsi pemakai atau konsumennya. Hal ini terlihat jelas pada bidang fashion seperi beberapa merek desainer terkemuka Louis Vuitton yang memakai logo LV pada setiap produk dan kemasan produk serta mampu menaikan gengsi dari para pemakainya. Semuanya ini dikarenakan oleh kebiasaan manusia yang lebih mudah untuk mengingat sebuah gambar atau simbol dalam mengenali sesuatu yang baru. Karenanya tidak jarang para konsumen membeli sebuah produk berdasarkan bentuk, simbol atau gambar yang mereka ingat tertera dalam kemasan produk walaupun sebenarnya mereka lupa akan nama produk tersebut.

Tagline dan logo merupakan dua hal yang sering dilupakan para pebisnis online. Padahal dua bagian ini merupakan identitas utama suatu bisnis. Dengan tagline dan logo, suatu bisnis akan lebih mudah dikenal dan diingat. Untuk membuatnya pun tidak bisa asal jadi, sebab tagline dan logo bisa punya pengaruh besar ke bisnis. (Politwika, 2017:23)

Banyak dari pelaku industri skala kecil menengah (UKM) berkilah dengan menyatakan bahwa perusahaan mereka masih kecil atau pemain baru dan karenanya memiliki alasan untuk tidak mencantumkan logo pada kemasan produk atau pada produk mereka seperti Blackberry, Nokia, Louis Vuitton, Honda dan sebagainya. Perlu diketahui bahwa kesemua perusahaan besar tersebut memulai perusahaannya berpuluh-puluh tahun yang lalu dari kecil dan telah menyadari pentingnya logo serta melakukan secara konsisten program marketing dan branding dengan mencantumkan logo mereka pada kemasan produk. 
Sebagaimana Elvita Bakery and Cake dalam memulai usahanya semenjak satu tahun terakhir ini, baru menyadari bahwa pentingnya sebuah logo yang harus tertera di kemasan aneka produknya.

Pemberian kriteria untuk menentukan keberhasilan sebuah logo sulit dilakukan karena sebuah logo yang sukses tidak dapat berdiri sendiri. Selain dengan logo, citra sebuah perusahaan atau produk yang diiklankan harus didukung dengan usaha lain agar diperoleh kesan atau anggapan yang mendalam dari mata para audiensnya. Manakah yang lebih dahulu dikenal ; audiensi, citra produk, atau logonya itu sendiri? Secara alamiah, seseorang biasanya mengenal ciri logo terlebih dahulu. Oleh karena memperoleh kesan yang baik (menarik, simpatik) sehingga di dalam imajinasi orang tersebut, produk yang diwakili oleh logo itu sebaik yang dibayangkan. (Adi Kusrianto, 2007 : 232).

Berdasarkan hasil analisis situasi mitra di atas, dapat diambil gambaran bahwa Elvita Bakery and Cake perlu memikirkan tentang konsep logo yang harus dibuat, mengingat kemasan aneka produknya mulai dalam tahap perbaikan dan peningkatan secara visual. Maka diperlukan adanya sebuah pendampingan intensif terkait dengan pembuatan logo perusahaan.

Beberapa langkah untuk menyelesaikan pembuatan logo Elvita Bakery and Cake adalah membahas tentang konsep apa yang ingin disampaikan oleh Elvita Bakery and Cake melalui logo yang akan dibuat kemudian mendampingi secara teknis pembuatan logo Elvita Bakery and Cake.

Berdasarkan permasalahan yang dihadapi mitra dalam hal ini adalah Elvita Bakery and Cake, maka ketua pengusul mempunyai terget yang akan didapatkan sesudah kegiatan. Adapun target tersebut adalah terselesaikannya pembuatan logo Elvita Bakery and Cake sesuai dengan konsep yang diinginkan oleh pemilik perusahaan.

\section{METODE PELAKSANAAN}

Metode pemecahan masalah yang dianggap tepat dalam pengabdian ini adalah berupa model pendampingan secara intensif, diskusi dalam membahas konsep logo yang diinginkan oleh pemilik usaha ini, serta mendampingi secara teknis pembuatan logo tersebut. Adanya keterbatasan pengetahuan dan keterampilan dari pemilik usaha dalam menggunakan software photoshop menjadi fokus dalam proses pendampingan ini.

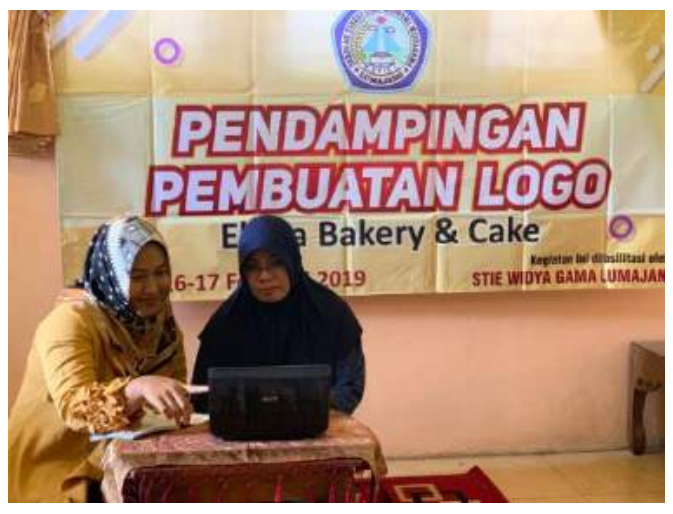

Gambar 2

Kegiatan Pendampingan Pembuatan Logo Elvita Bakery and Cake 


\section{HASIL DAN PEMBAHASAN}

Hasil yang telah dicapai dalam pengabdian ini adalah terselesaikannya pembuatan logo Elvita Bakery and Cake sesuai dengan konsep yang dikehendaki oleh pemilik perusahaan. Berikut adalah langkah-langkah pembuatan logo :

1. Buka software Photoshop minimal Versi CS6.

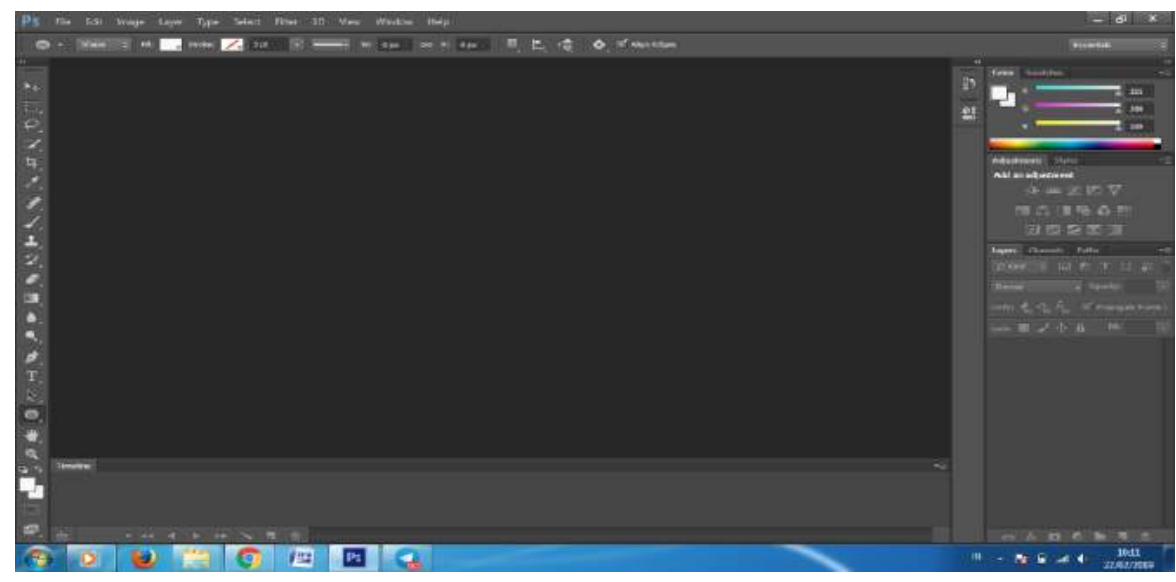

2. Pilih File, New

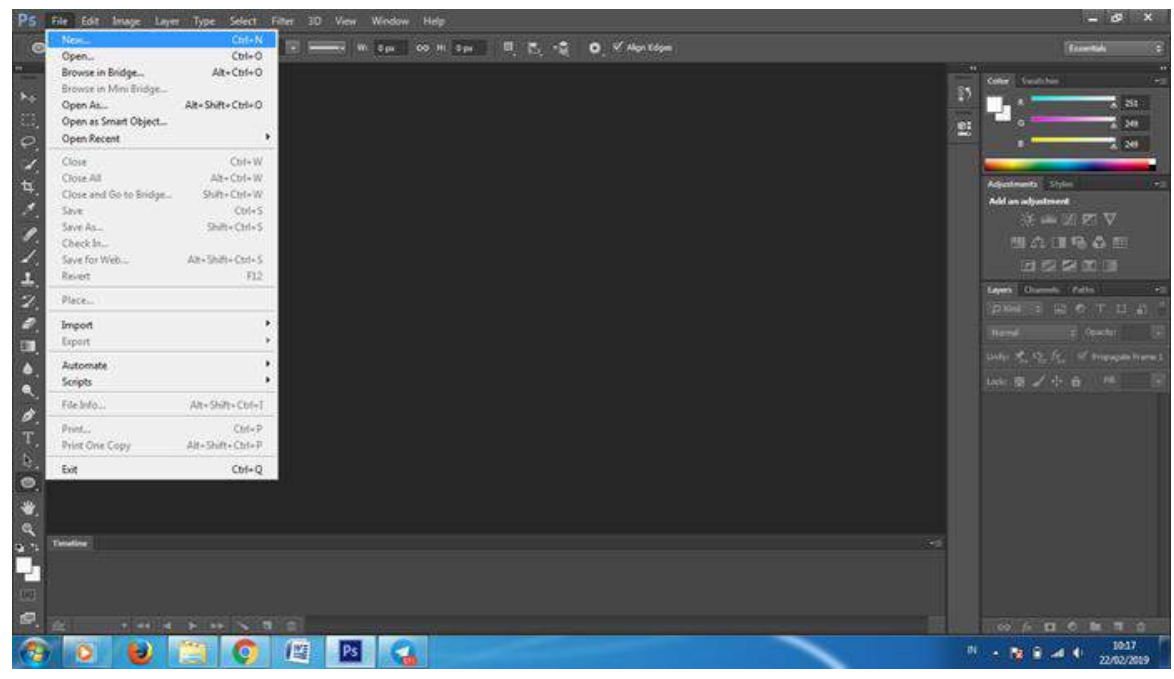

3. Beri nama file dan atur Widht, height dll, lalu tekan OK

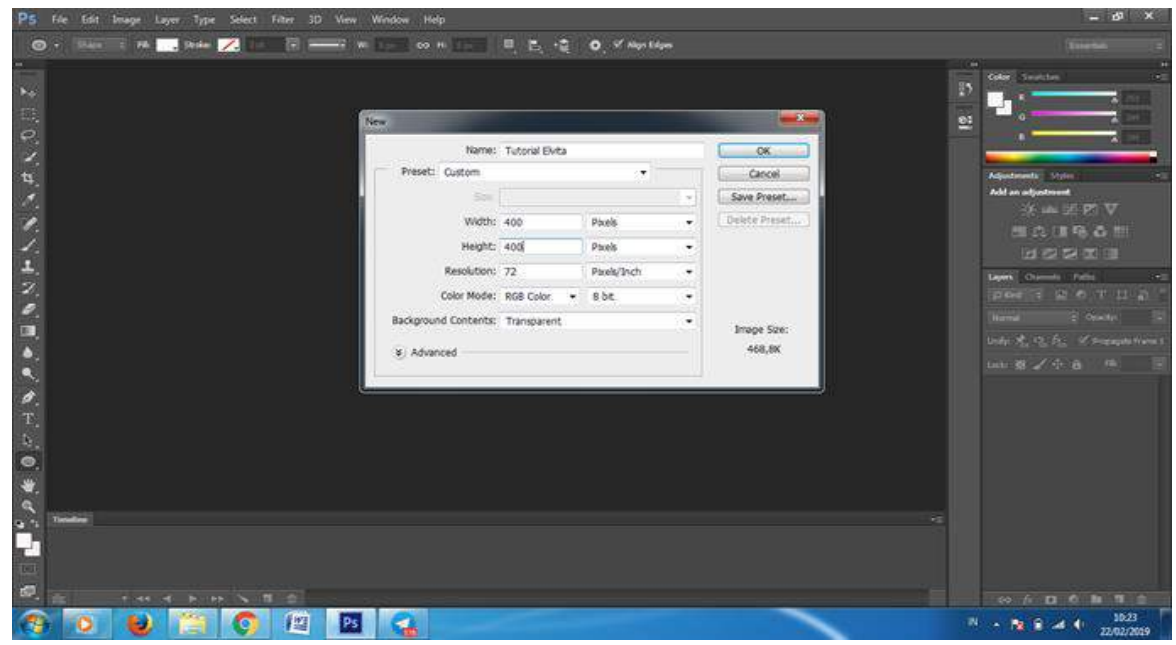


4. Muncul kotak seperti ini

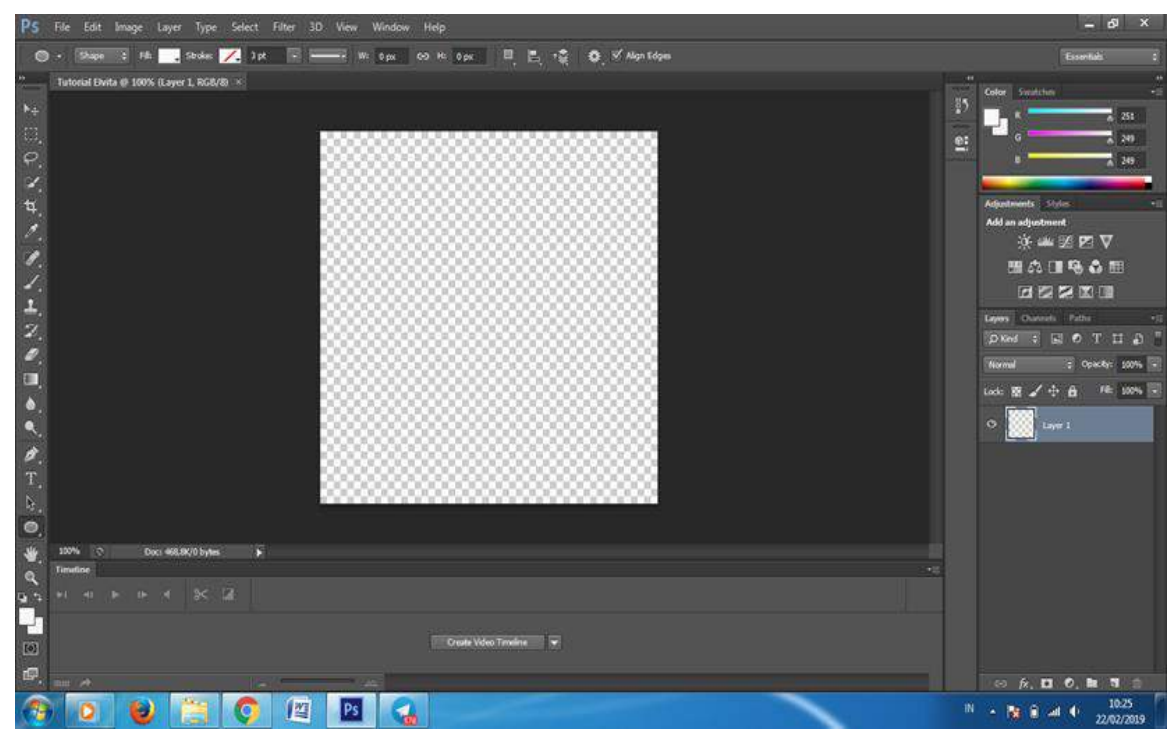

5. Pilih Ellips Tool

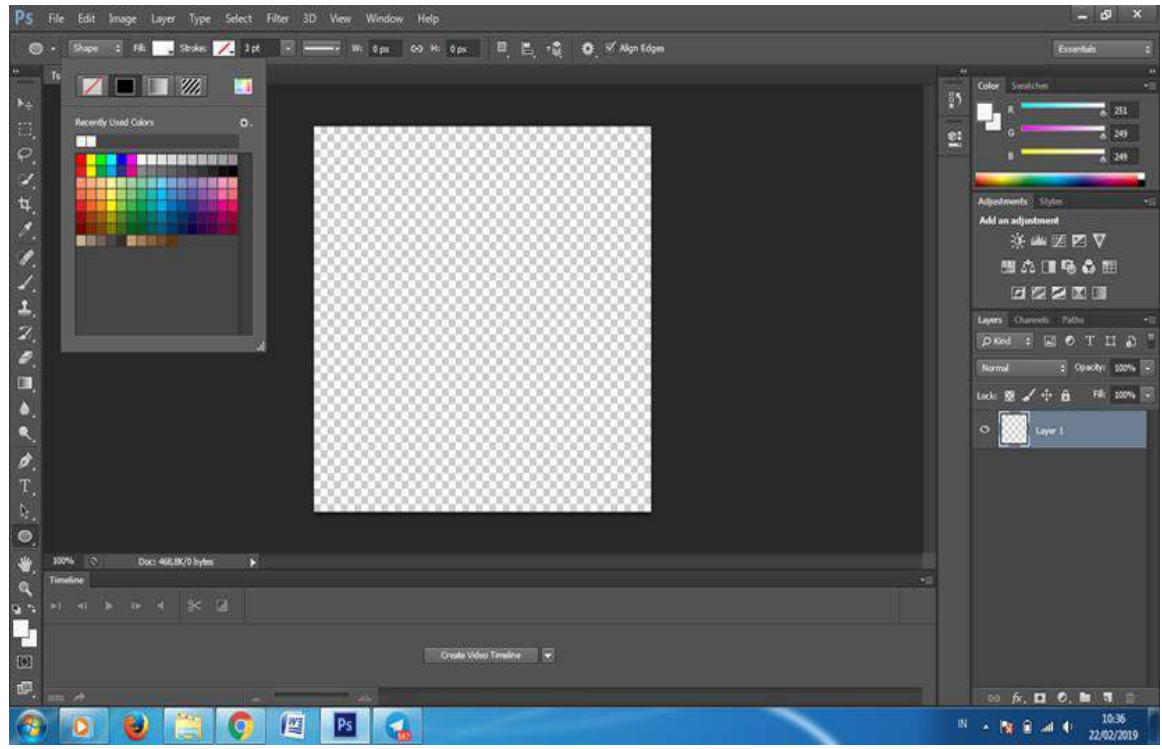

6. Fill pilih warna putih

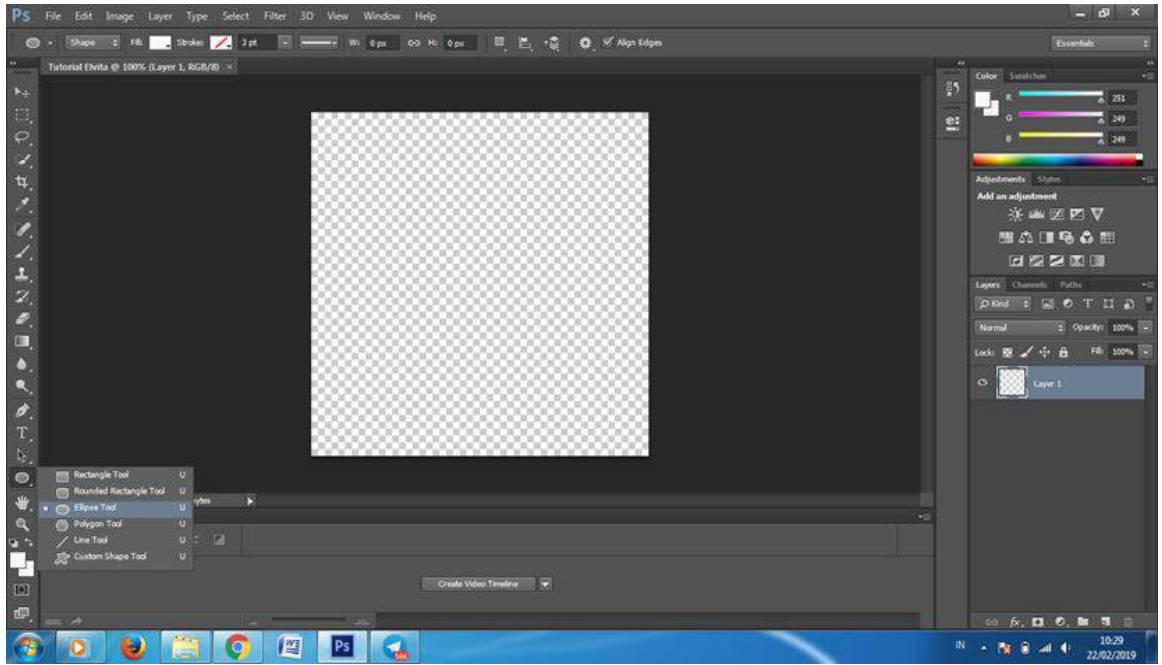


7. Stroke pilih warna putih

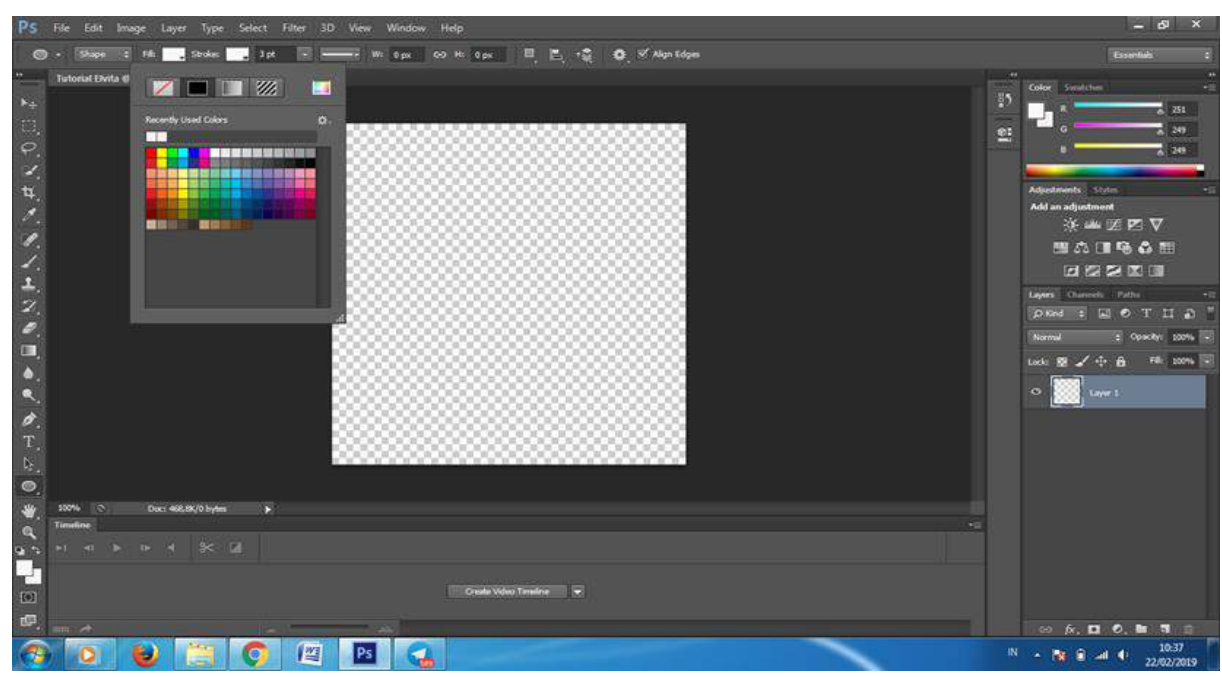

8. Garis pilih lurus

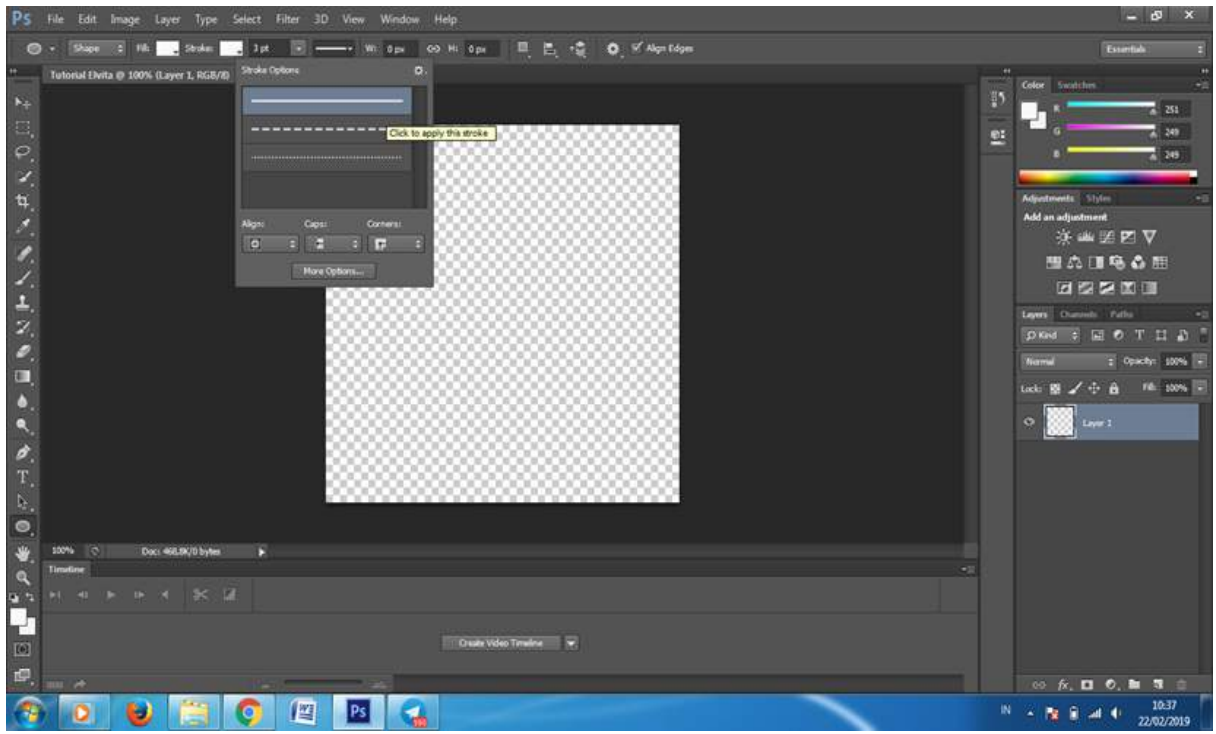

9. Drag membentuk lingkaran

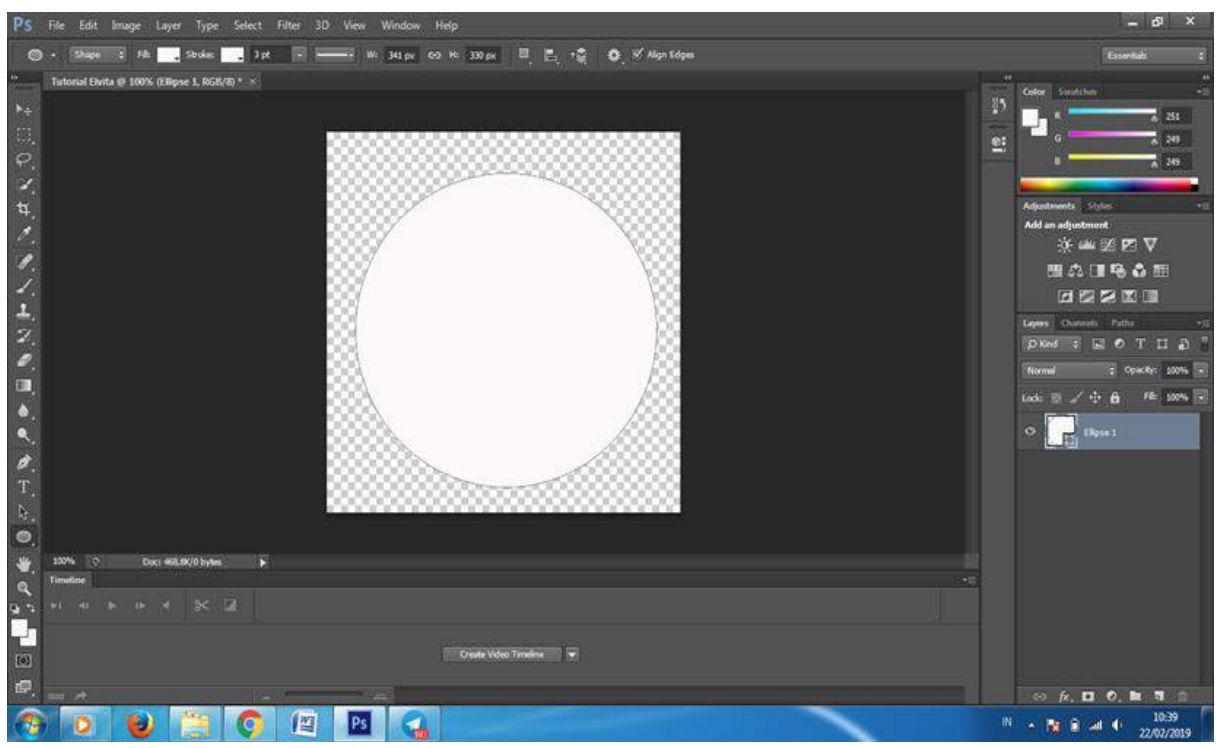


10. Klik Hand tool sehingga posisi seperti ini

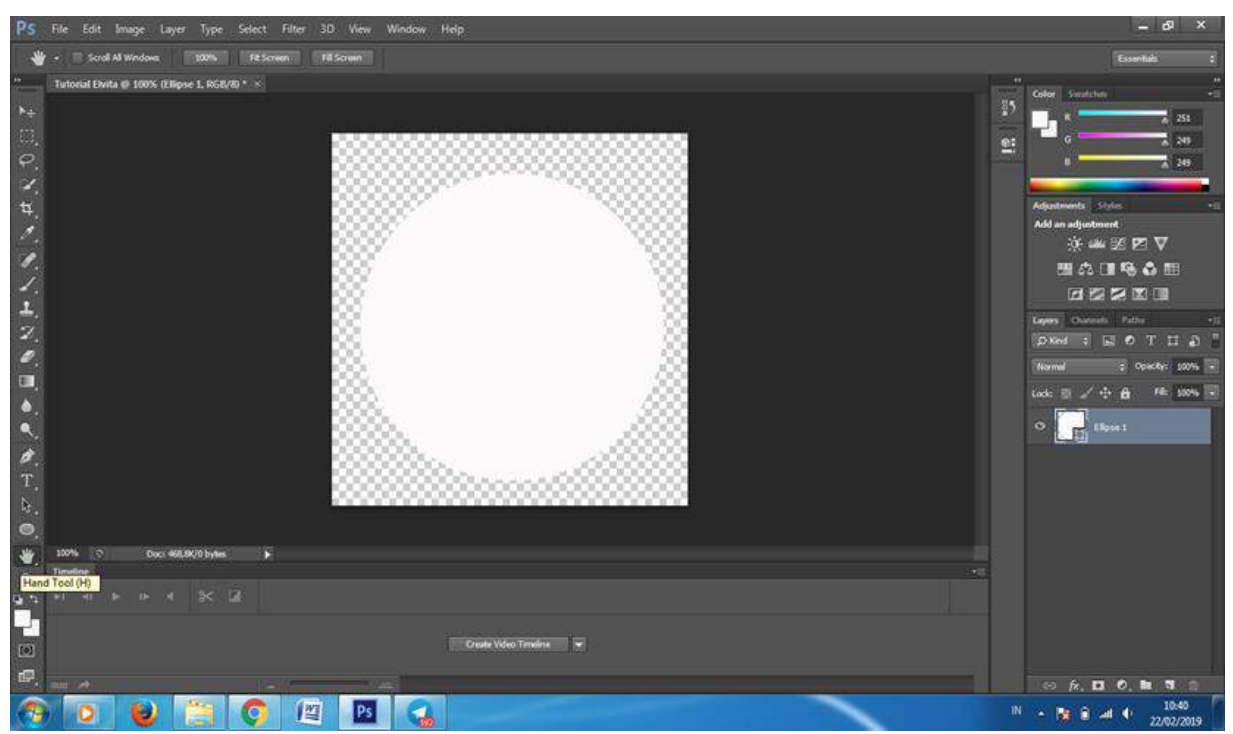

11. Rapikan posisi lingkaran ada di tengah2 kotak, akhiri dg hand tool

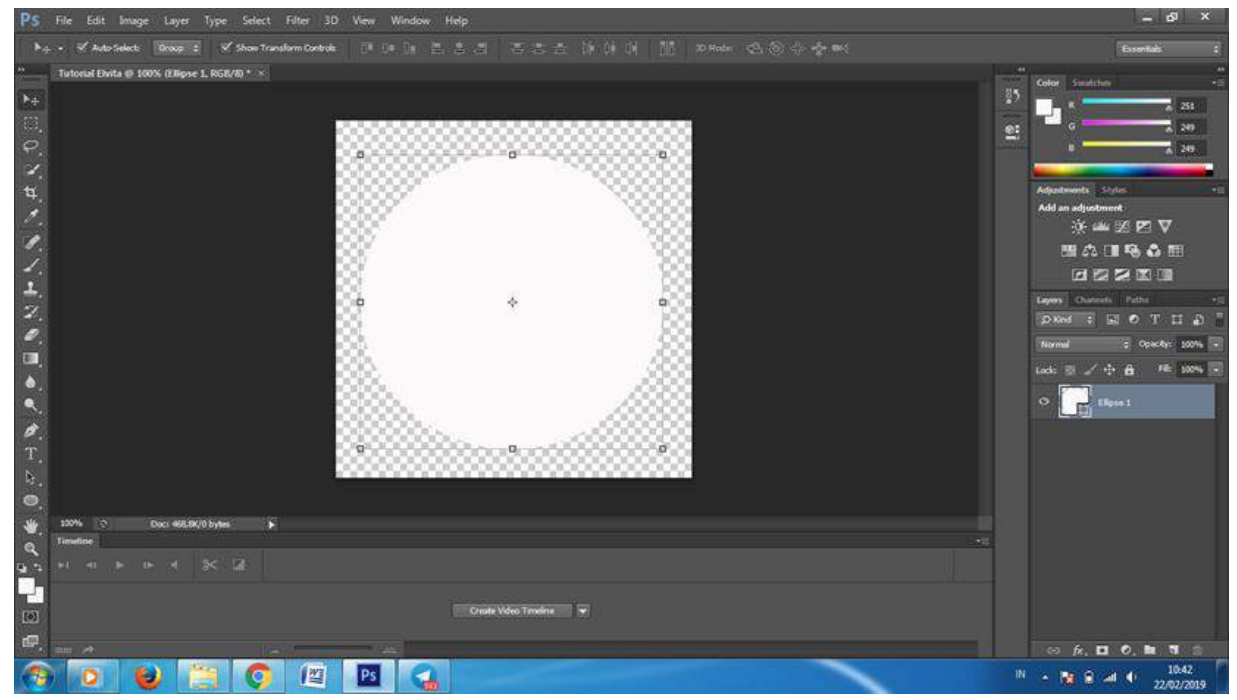

12. Klik Create new layer

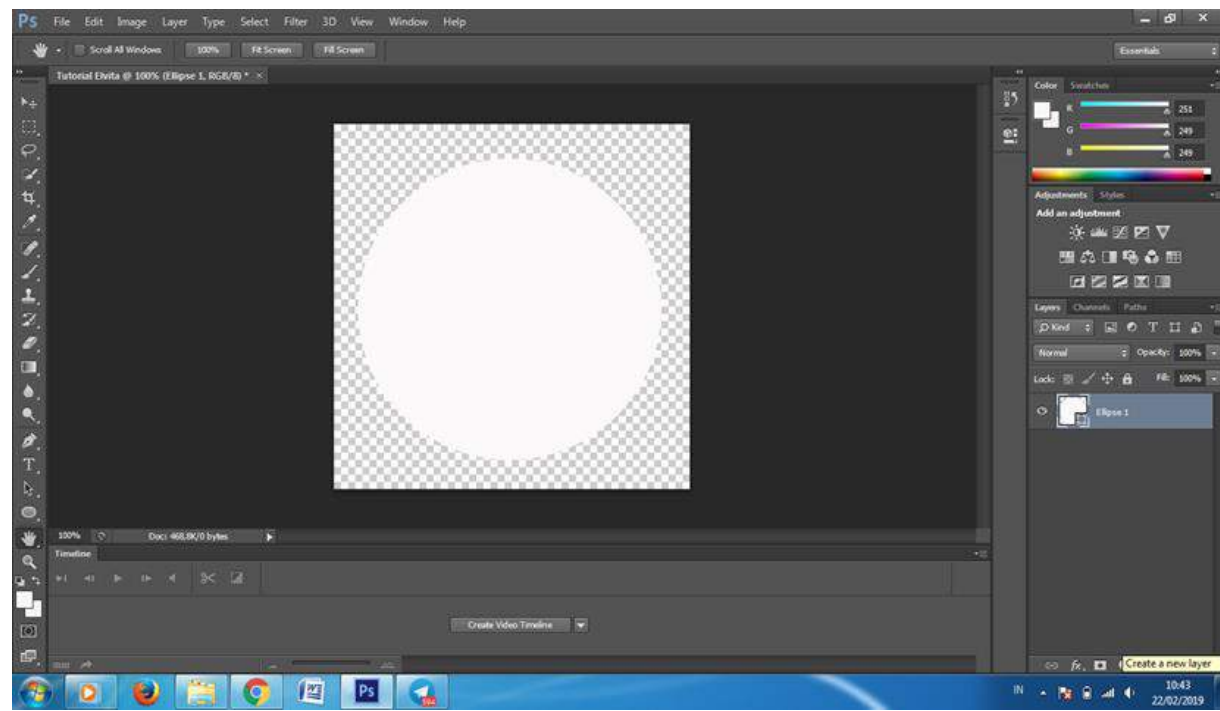


13. Pilih ellipse tool lagi

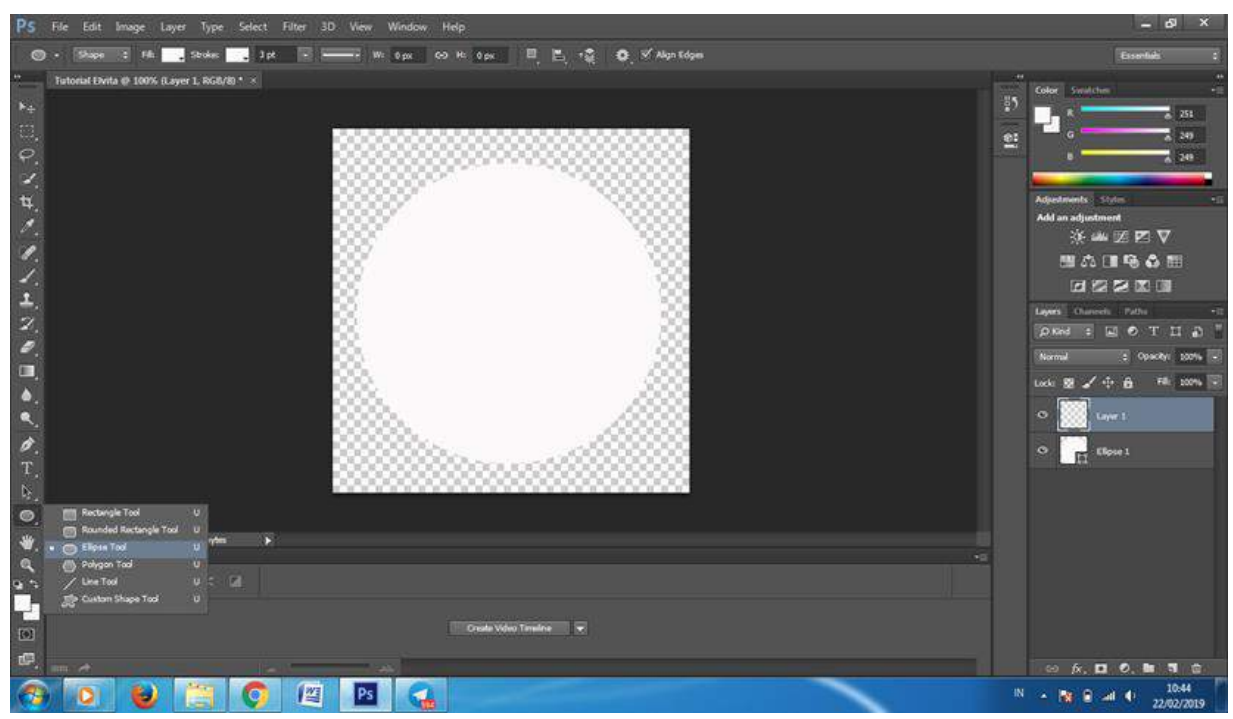

14. Pilih fill itu

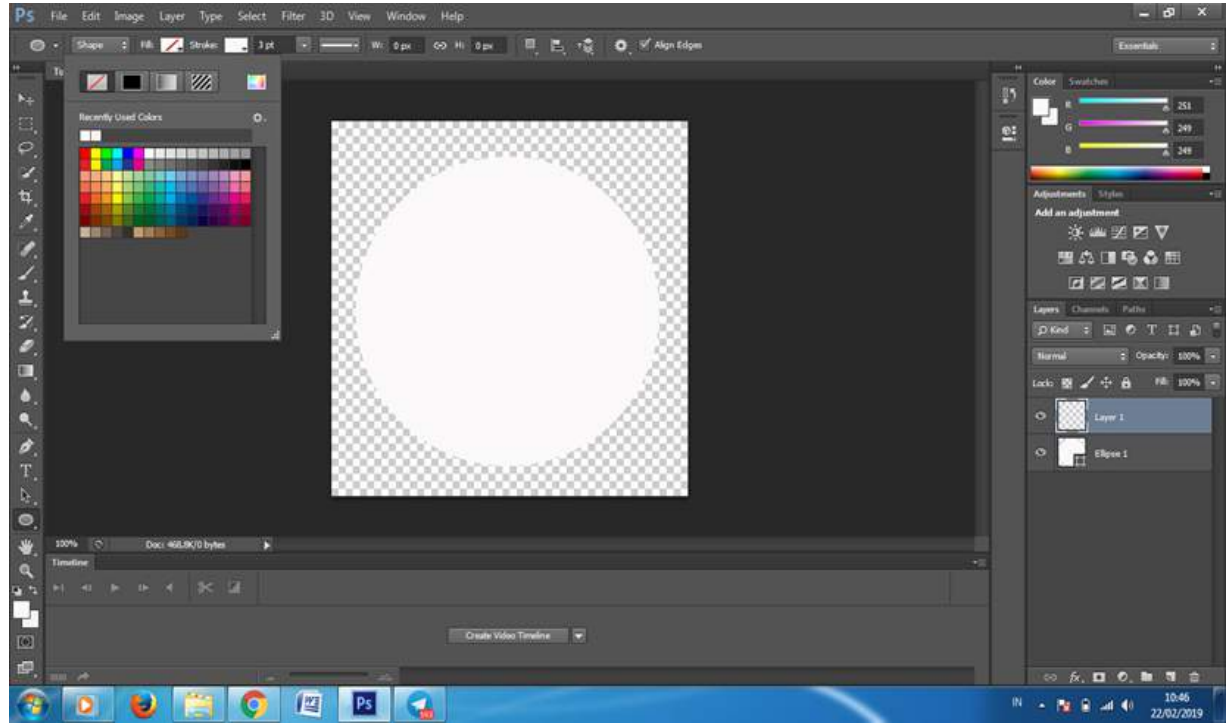

15. Pilih stroke warna ungu

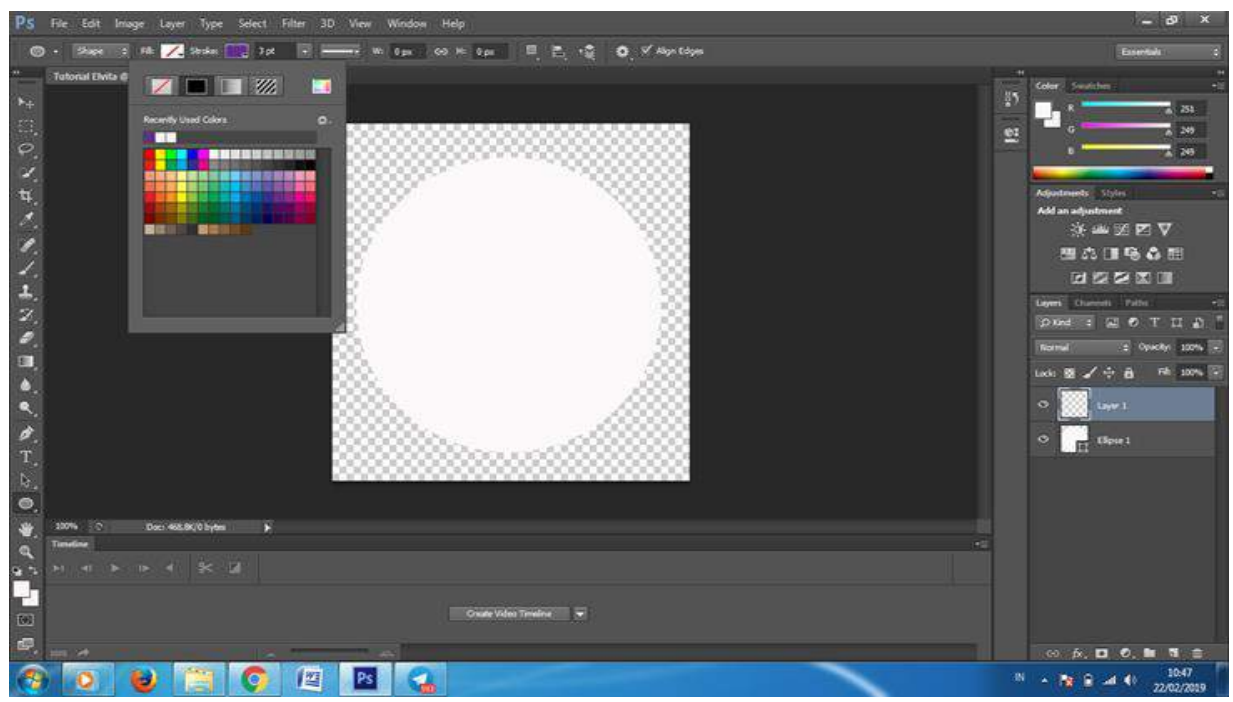


16. Pilih garis putus-putus

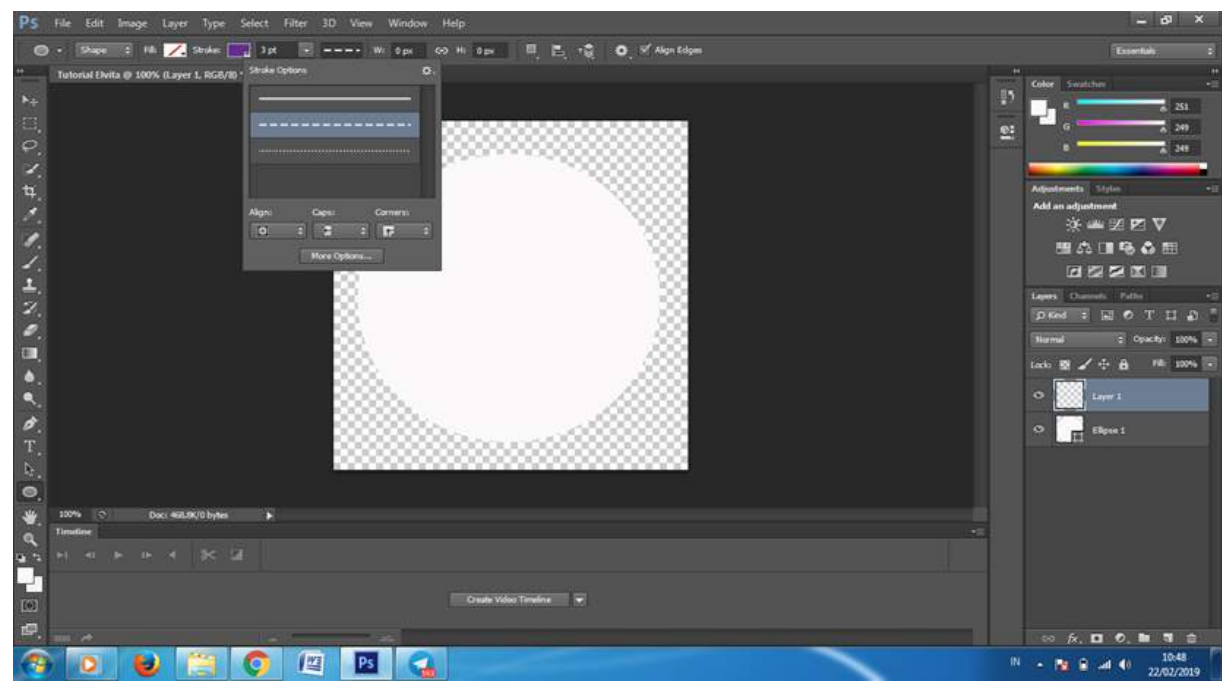

17. Drag di tengah-tengah lingkaran yg pertama

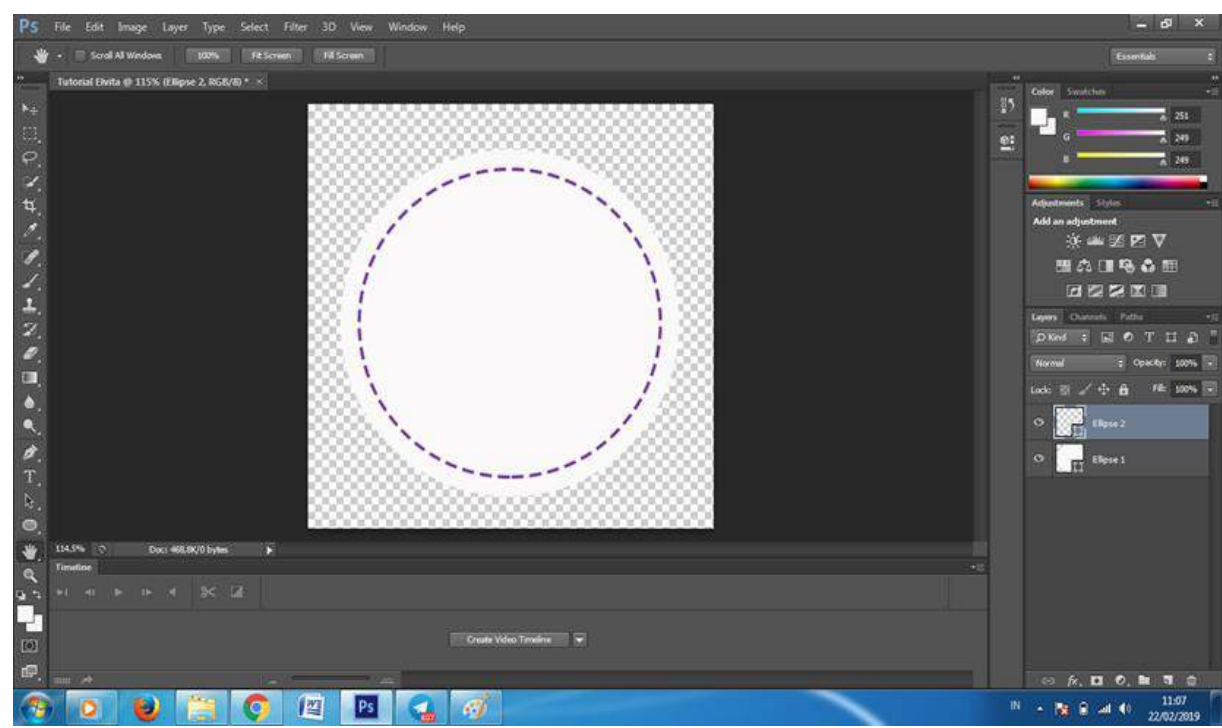

18. Klik ikon $\mathrm{T}$, kemudian drag di tengah lingkaran

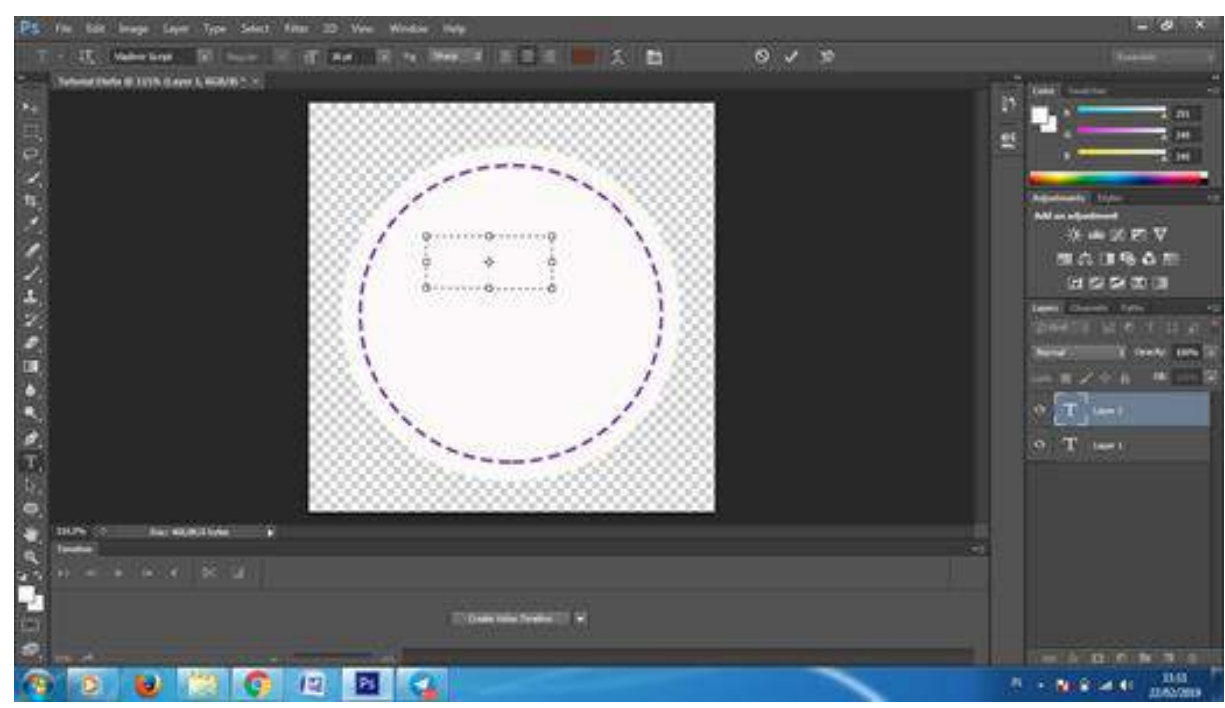


19. Ketik Tulisan dg menggunakan ikon $\mathrm{T}$

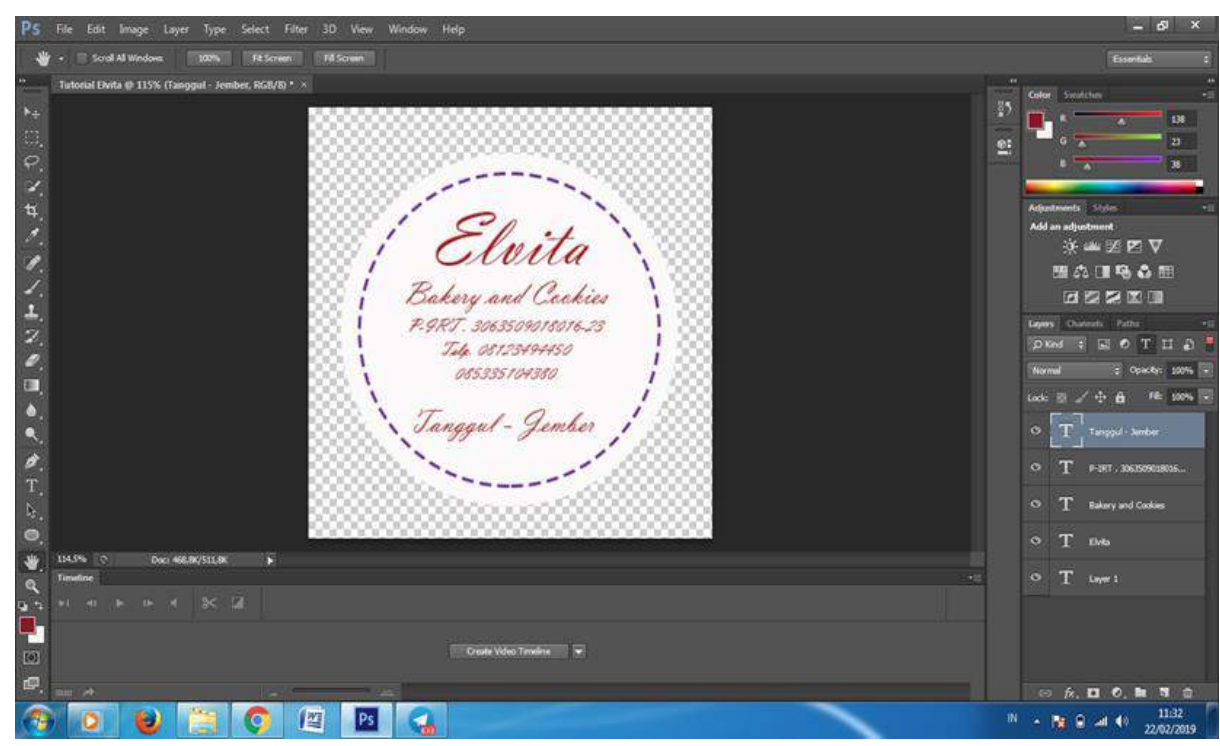

20. Tulisan Tanggul Jember sesuaikan dengan Menu ikon T, pilih Arc

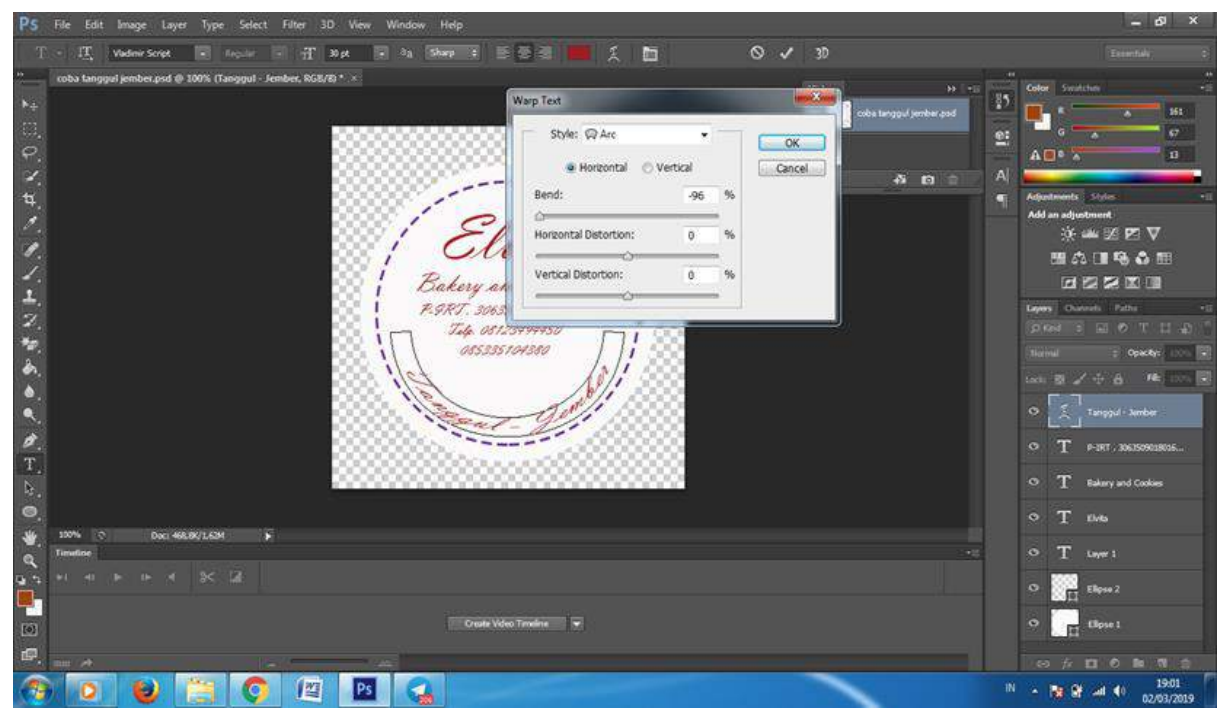

21. Donlot Flower icon di Shutterstock
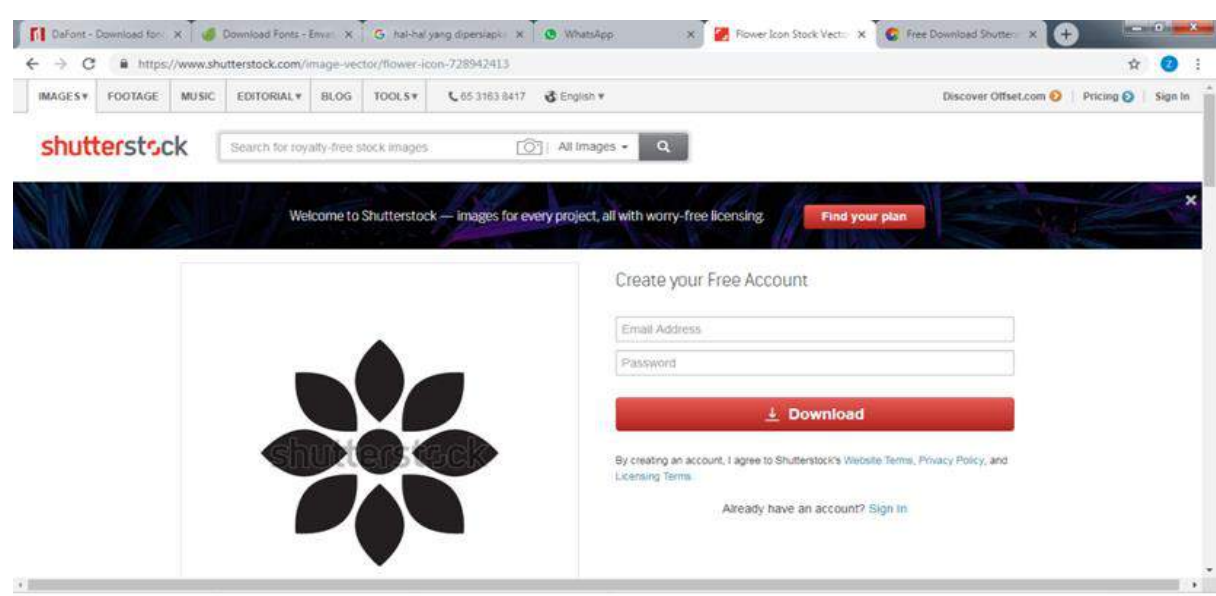

Create your Free Account
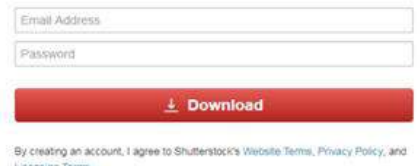

Areacy nave an accounn sign in

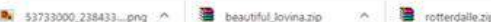

(9) D $D$ A 
22. File, open, hasil donlot flower icon di photoshop shg tampil di tab baru

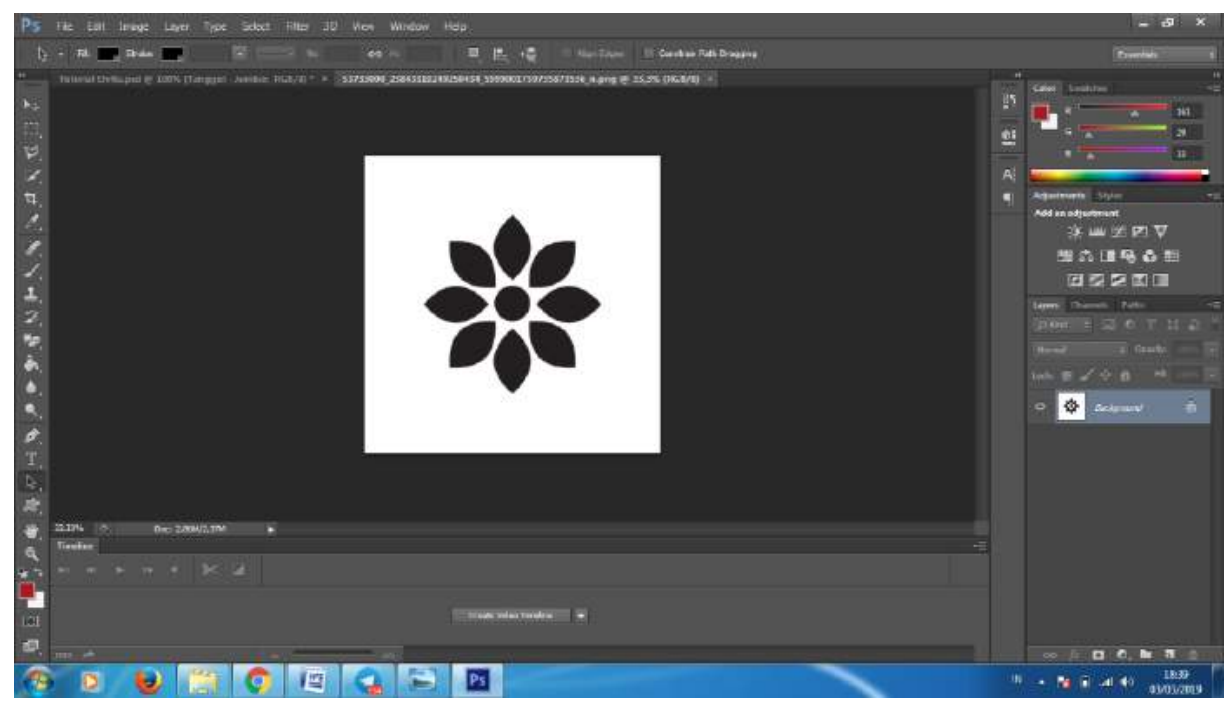

23. Move tool tab flower icon ke tab logo

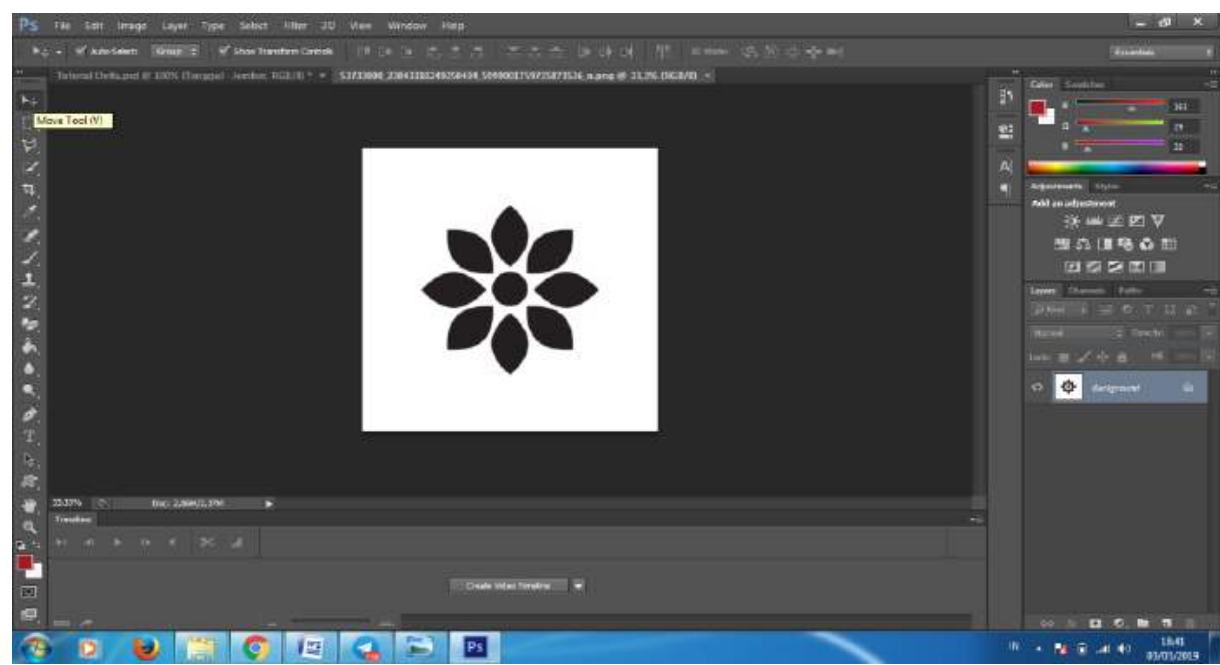

24. Drag ke tab logo sampai tampil seperti ini

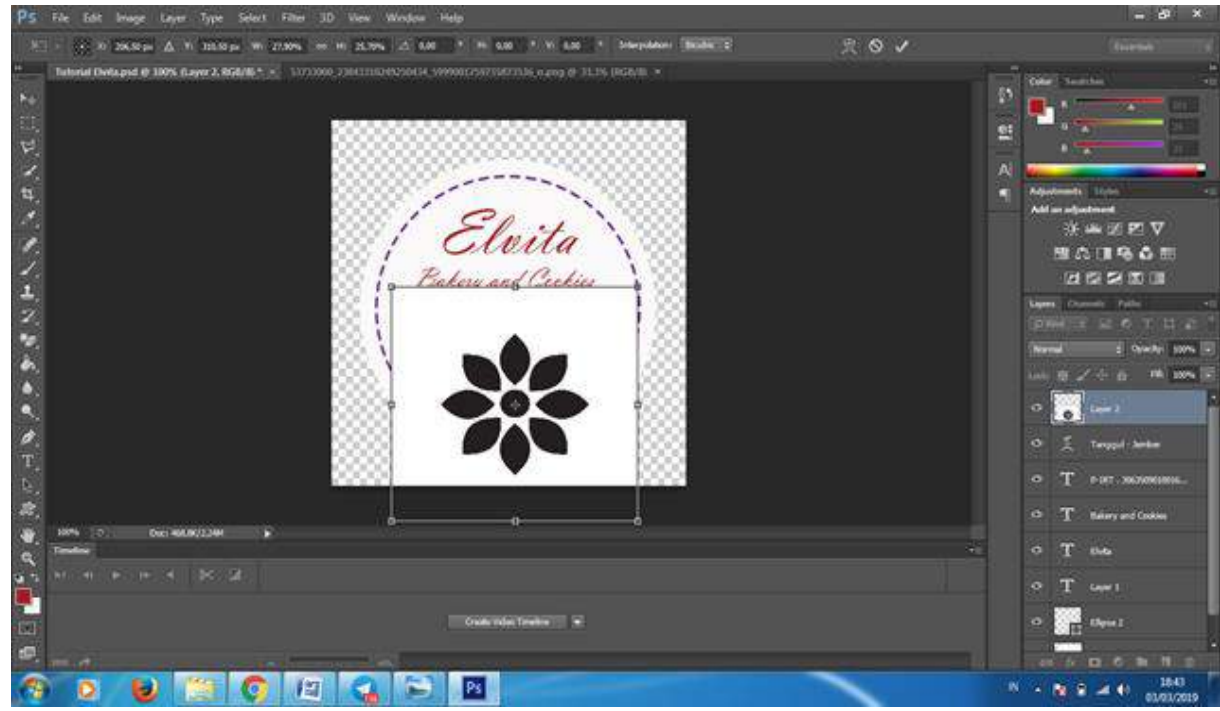


25. Pilih poligonal lasso tool kmd gambar pd wilayah yg akan dicrop

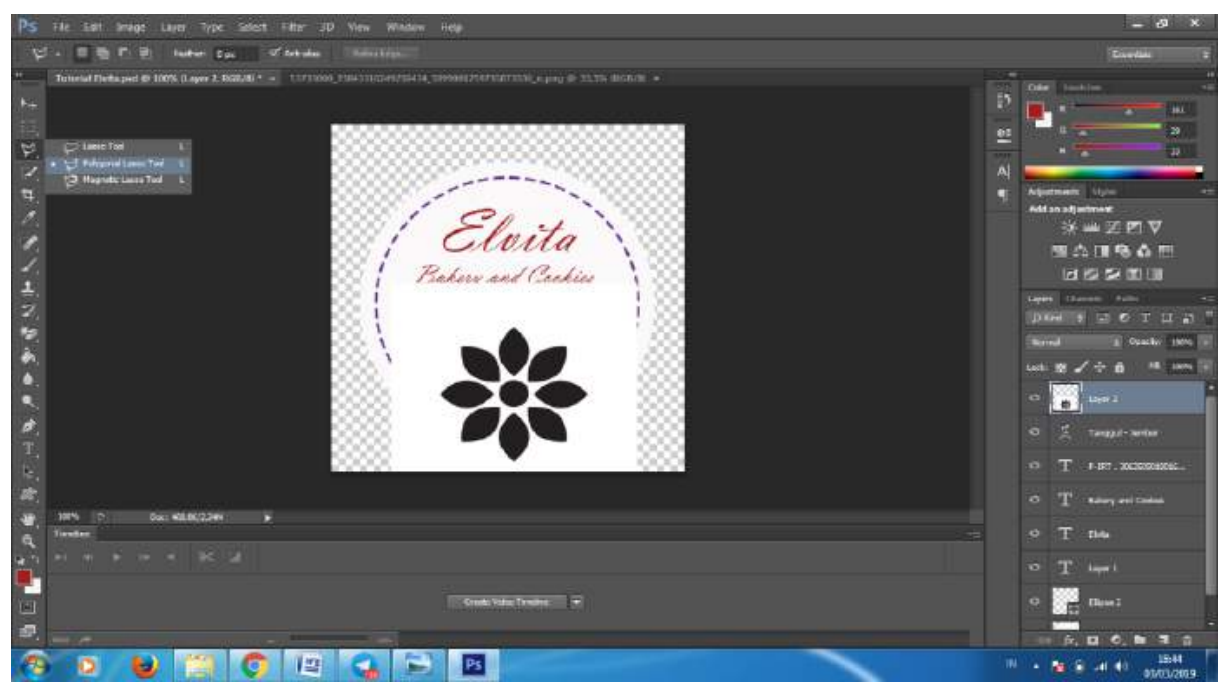

26. Lepas alt sehingga tampil spt ini

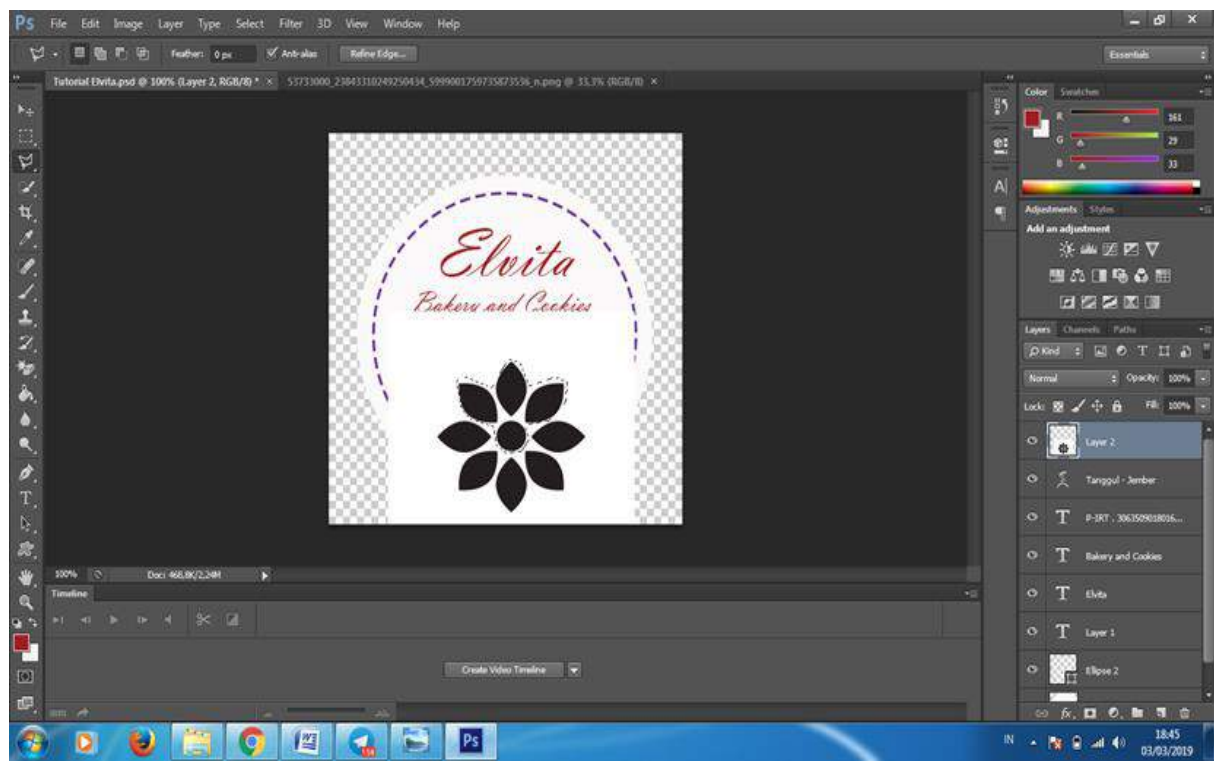

27. Arahkan kursor ke layer dua dan klik cntrl j

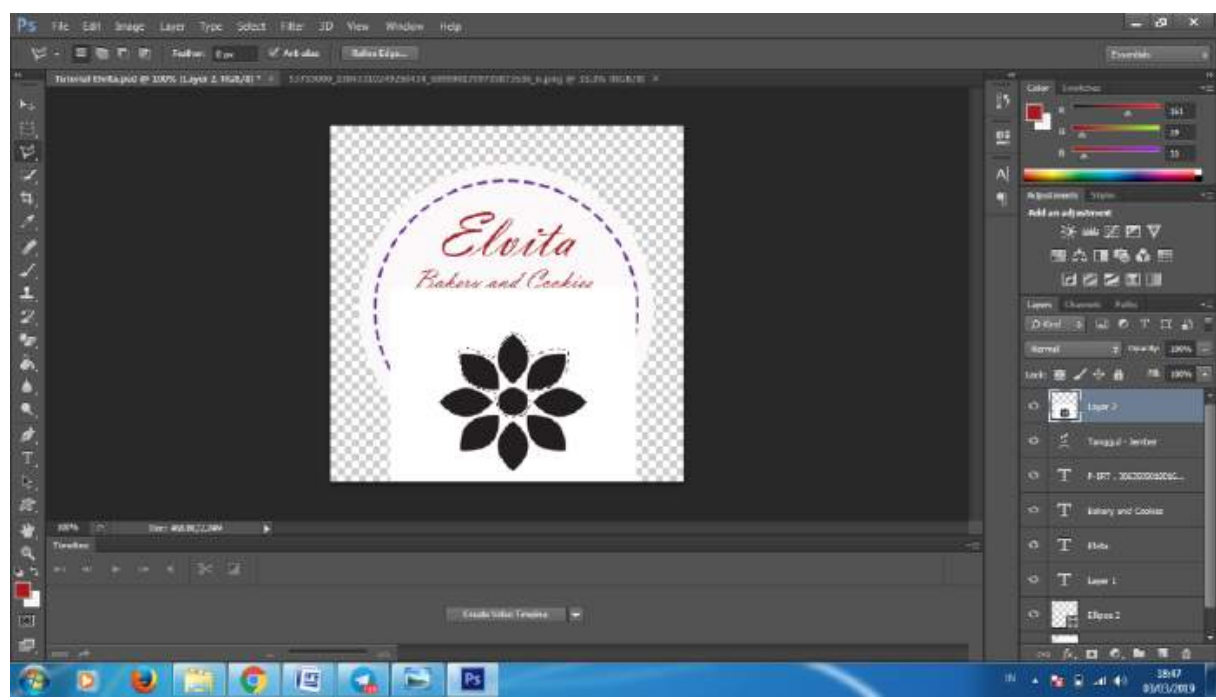


28. Bagian yg dicrop sudah tampil di layer 3

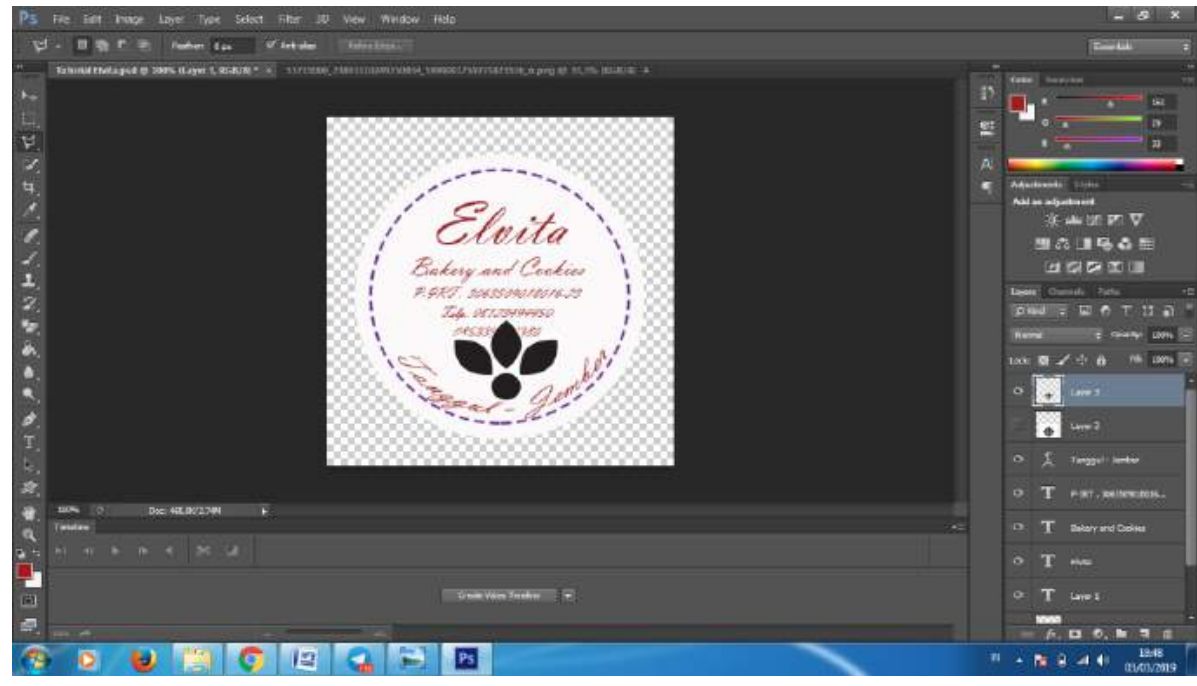

29. Klik Move tool di gambar bunga, kmdn atur besar kecilnya dan drag ke posisi yang diinginkan

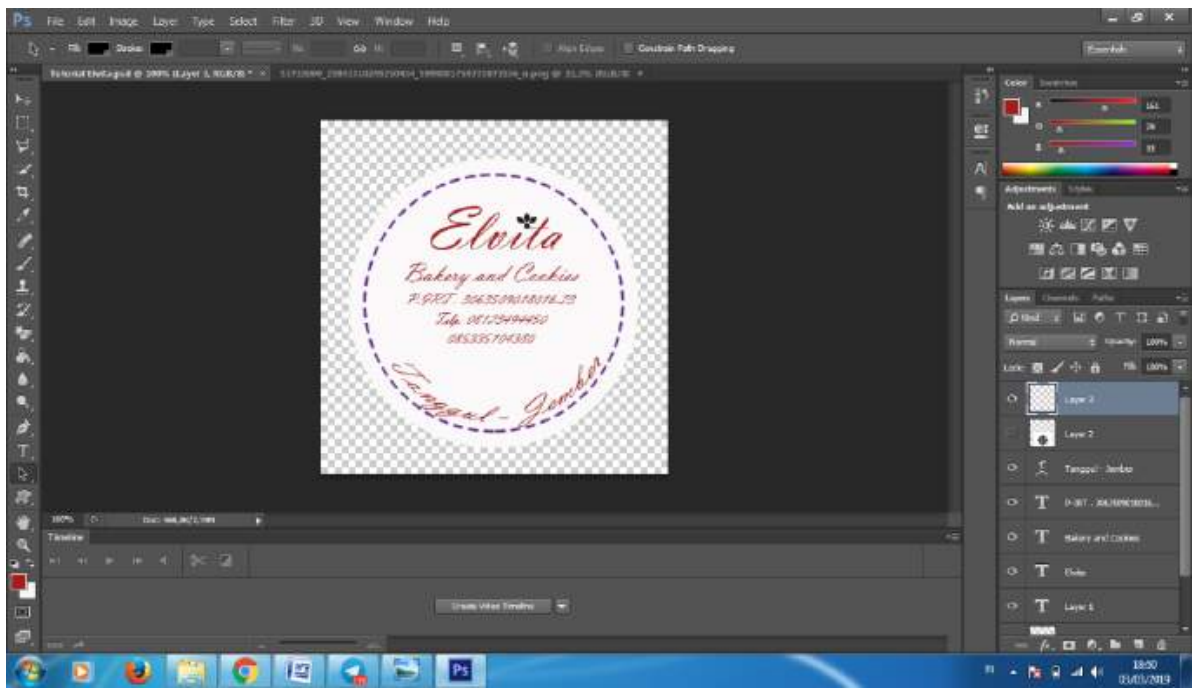

30. Pilih magic wand tool, klik warna bunga yg akan diganti warna dg shift

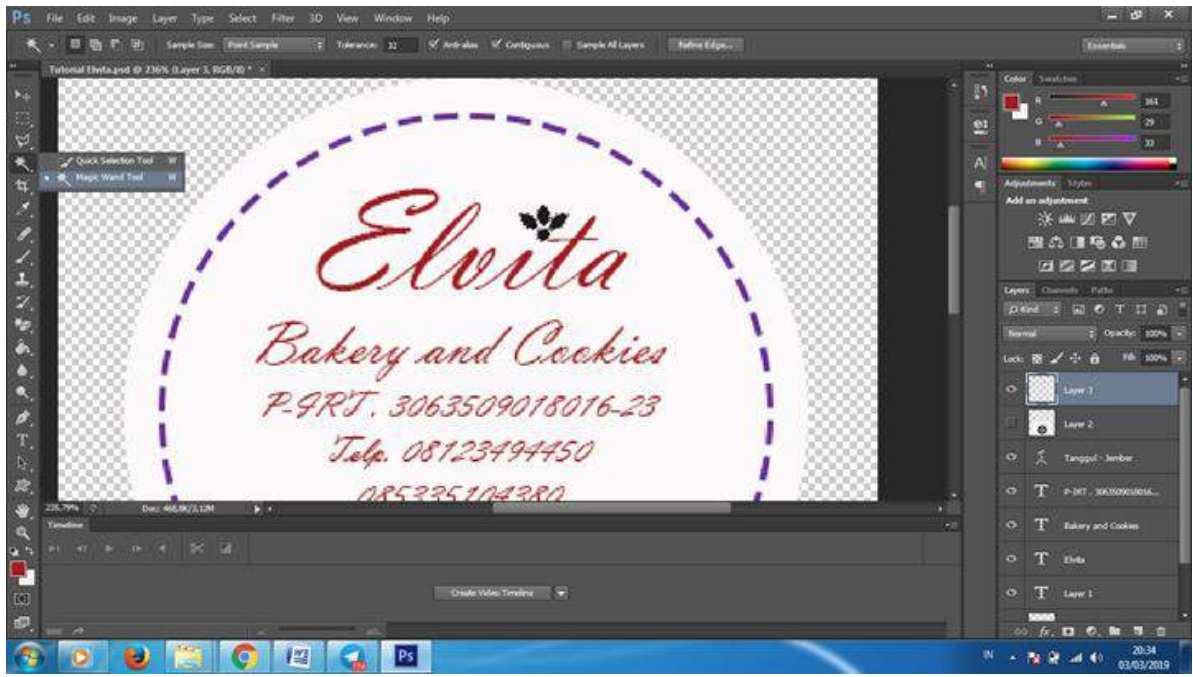


31. Klik warna yang diinginkan, klik ok

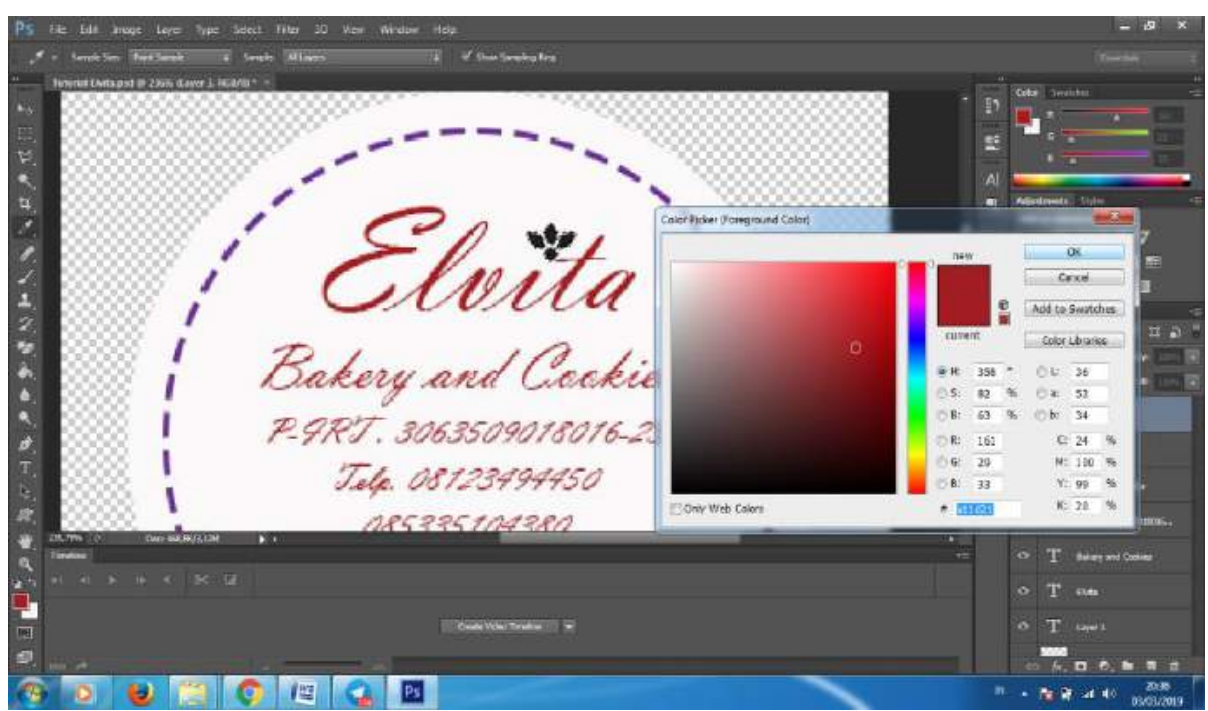

32. Klik Brush tool, sapukan ke bunga yg akan diwarnai

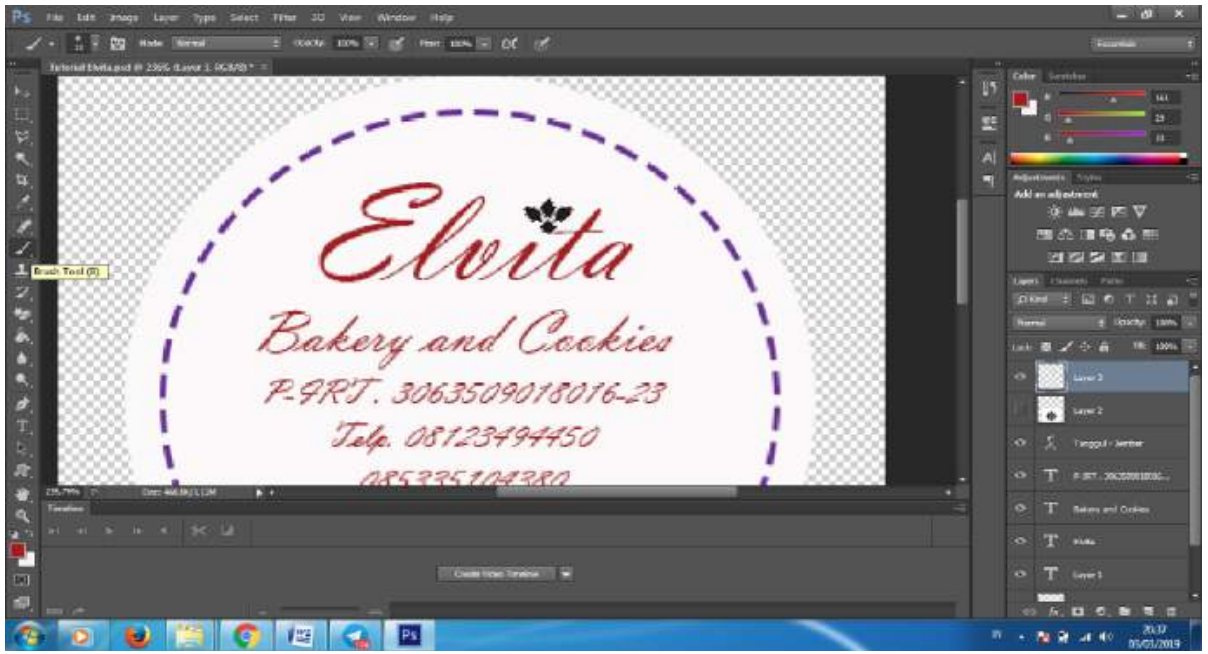

33. File. Save as, Beri nama file, rubah ke jpg, klik ok

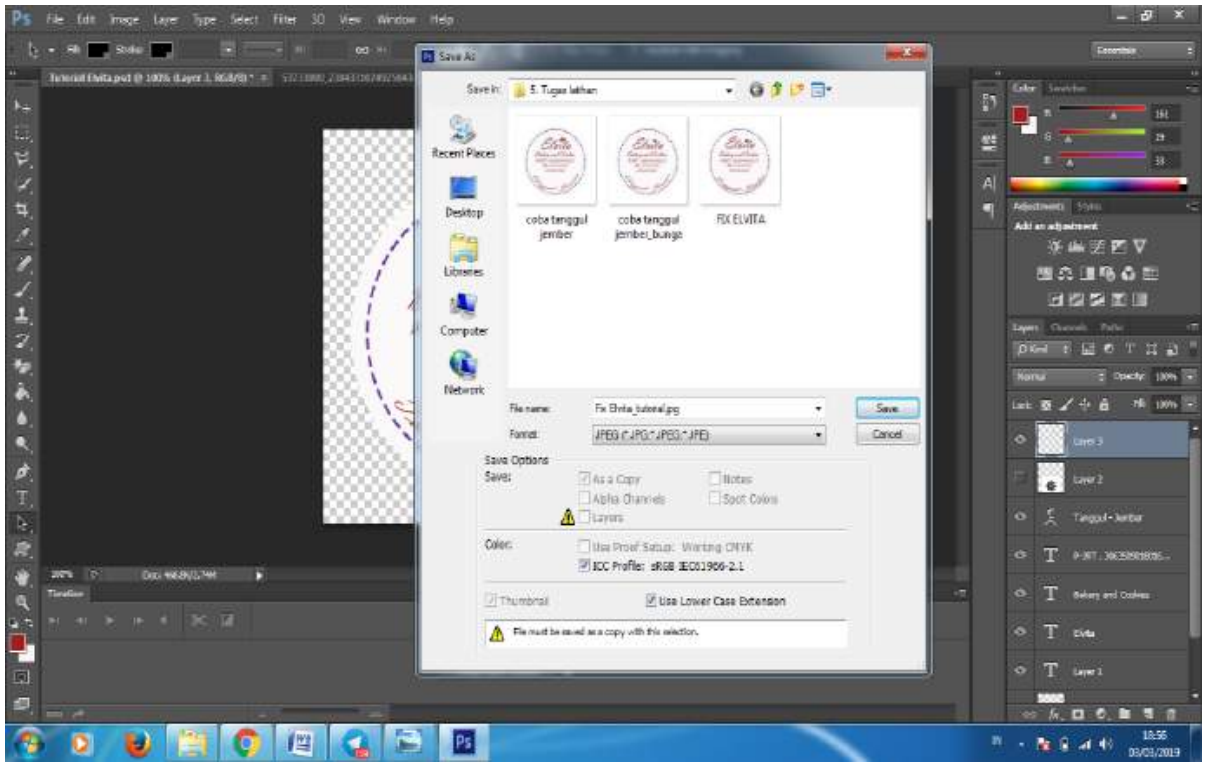




\section{KESIMPULAN}

Berdasarkan uraian di atas, kesimpulan yang dapat diambil dari kegiatan Pengabdian Kepada Masyarakat Sekolah Tinggi Ilmu Ekonomi Widya Gama Lumajang bersama mitra yaitu pemilik usaha Elvita Bakery and Cake Kecamatan Tanggul, Kabupaten Jember dibagi menjadi empat kegiatan, yaitu:

1. Pembahasan tentang konsep logo Elvita Bakery and Cake.

2. Menentukan warna dan ukuran logo yang diinginkan oleh pemilik usaha.

3. Mengaplikasikan ide, warna, ukuran serta identitas apa yang akan ditampilkan dalam logo.

4. Finalisasi pembuatan logo.

Berdasarkan uraian di atas, dapat disajikan beberapa saran demi kemajuan mitra yaitu pemilik usaha Elvita Bakery and Cake dalam pembuatan logo perusahaan :

a. Memperhatikan warna dan ukuran yang digunakan dalam logo.

b. Mengutamakan aspek simplicity (simpel)

c. Logo harus mencerminkan sikap aktif dari perusahaan

d. Visualisasi logo harus mudah diingat

e. Berkreasi dengan jenis-jenis font yang tertuju pada target pasar

f. Harus memiliki keunikan tersendiri.

\section{DAFTAR PUSTAKA}

Kusrianto, Adi. 2007. Pengantar Desain Komunikasi Visual. Yogyakarta : CV. Andi Offset.

Politwika. 2017. 99 Langah Sukses Berbisnis E-Commerce. Jakarta : Penerbit Gramedia Widiasarana Indonesia.

Suwatno. 2017. Komunikasi Pemasaran Kontekstual. Bandung : PT. Remaja Rosdakaraya Offset. 